\title{
EXPERT SYSTEMS TECHNOLOGY IN THE DOMAIN OF CONSTRUCTION
}

\author{
By
}

\author{
Satish Mohan \\ Department of Civil Engineering \\ State University of New York at Buffalo \\ Buffalo, New York 14260, USA
}

\section{Introduction}

As of today, the human knowledge of a domain or the art and science of performing specific tasks successfully, is either dispersed in books and journals or exists in the minds of experts. Books and journals do store large volume of knowledge, but before that knowledge can be applied, one must read it, understand it and then decide how to use that knowledge for solving a specific problem. This limits the use of knowledge to a small group. Also, since a book rarely defines the 'how' of performing a given task, the knowledge could be misinterpreted and wrongly applied. Expert systems technology, which is now emerging, uses the power of today's chip and stores knowledge electronically. The stored knowledge is then available to users, who have no knowledge of computer science, in a friendly manner using natural languages like English. A definition of an expert system can be given as below:

An Expent System is a computer program that provides expert level solutions to domain specific problems (1) and is:

o Heuristic: It combines the judgemental knowledge of human experts with the factual knowledge.

o Transparent: It provides explanations of its line of reasoning and answers queries about its knowledge.

o Flexible: It adds new knowledge incrementally to its existing store of knowledge, and deletes or modifies any portion of the existing knowledge easily without affecting the total knowledge base. 
o Simple to Build \& Use: Expert systems are implemented in high level application languages or domain independent shells and thus take much less time and effort than the conventional programming languages.

o Willing: It can accept uncertain data and also incomplete data, and can thus solve ill-structured problems.

o Intelligent: An expert system can check any contradictions, and can link knowledge to create new rules.

With the above properties existing as their essential constituents, expert systems have very justifiably drawn the attention of the business community. They will soon become popular aids in problem solving and decision making.

\section{Applicability of \\ Expert Systems Technology in Construction}

Because of their above described characteristic attributes of combining factual knowledge with judgement, being able to handle incomplete and uncertain data, and communicating with their users in a natural language like English, expert systems have a special appeal to the construction profession. The following typical features of today's construction environment show the need of an expert systems like technology:

o Unlike manufacturing, construction is non-repetitive, each project being different than the other in design, layout, materials used, construction methods, time, crews, weather and management.

- Construction environments are full of uncertainties in respect of labor \& equipment productivity, market forces, material availability and changes, variations in regulatory agencies' influence and variations in weather. Algorithmic computer progams cannot handle such uncertainties.

o So far, not enough domain knowledge has been formalized and encoded in text books, in the field of construction engineering and management. The industry runs on conventional knowledge and experience based judgement. This is very true in respect of the construction of temporary facilities, a first and an important task, where the construction is undertaken using local materials like wood and gravel with widely variable properties. 
- In many construction situations, there is not enough time to make a detailed analysis of all the influencing factors. Such decisions are often made on the spot so that the construction process is not interrupted. Expert systems can provide quick decisions in such situations.

- Many construction decisions like safety management, labor relations, decision to bid, bid evaluation and risk evaluation are qualitative and subjective in nature, needing heuristic approach.

o On a construction project, all the neccessary information on a subject is almost never completely known and the decisions have to be taken on the basis of incomplete information.

- Many construction professionals and managers do not have enough knowledge of computer science to be able to use and update algorithmic computer programs.

- Expert system building requires domain experts, and there are highly knowledgeable experts in the construction industry who have successfully completed several projects and who are widely recognized in the profession.

\section{State-of-the-Art Expert Systems in Construction}

The development of expert systems in the construction domain is in the very early stages and very few operational expert systems exist, today. However, a significant amount of activity is currently taking place in this area. A survey done in the middle of 1986, by the Construction Engineering Research Laboratory of the US Army Corps of Engineers, identified 28 expert system applications in the area of construction of which only 5 were operational i.e. , in routine use by persons other than their developers. Of the remaining, 12 existed as operational prototypes, 5 were under development and 6 were at the conceptual stage. Most of the expert systems developed so far are available on microcomputers, have the rule-based knowledge representation scheme and are implemented using commercial expert systems shells. Figure 1 summarizes some of the state-of-the-art expert systems in construction, detailing the input data requirements, system output, knowledge structure, control strategy, hardware required and the software used in the building of each expert system. Expert systems that are currently in the conceptual stage of development have not been included in Figure 1. 
Figure 1: STATE-OF-THE-ART EXPERT SYSTEMS IN CONSTRUCTION

\begin{tabular}{lll}
\hline EXPERT & & KNOWLEDGESTRUCTURE, \\
SYSTEM INPUT & OUTPUT & TOOLS, ORGANIZATION
\end{tabular}

\section{OPERATIONALEXPERT SYSTEMS}

WELDING

ADVISOR

- Type of materials involved

- Weld geometry

WELD DEFECT ADVISOR
- Weldprocedure

- Code requirements

- Site conditions

- Condition of failed weld
- Estimate of welding supplies

- Any special equipment list

- Causes of weld defects - Individual - System

- Advice to prevent poor welds
'KNOW-

HOW'

Transfer

Method

SAFEQUAL
- Risk reducing

- Possible risks
- Work package

o Risk
- Prequalification of contractors experience

- Safety Management practices

HICOST

- Preliminary design

- Cost estimate

Carnegie Mellon Univ. PA

\section{OPERATIONAL PROTOTYPES}

\begin{tabular}{|c|c|c|c|c|c|}
\hline $\begin{array}{l}\text { BERT- } \\
\text { Brickwork } \\
\text { Expert }\end{array}$ & 0 & $\begin{array}{l}\text { Design of } \\
\text { brickwork } \\
\text { cladding } \\
\text { Brick database }\end{array}$ & 0 & $\begin{array}{l}\text { Comments on } \\
\text { design quality } \\
\text { Suggestions for } \\
\text { improvements }\end{array}$ & $\begin{array}{l}\text { IBM PC, AUTOCAD, } \\
\text { LUCIFER; University } \\
\text { of Reading, UK }\end{array}$ \\
\hline
\end{tabular}




\begin{tabular}{|c|c|c|c|c|c|}
\hline MASON & $\begin{array}{l}0 \\
0\end{array}$ & $\begin{array}{l}\text { Basic duration o } \\
\text { estimate } \\
\text { Crew size } \\
\text { Quality of } \\
\text { materials }\end{array}$ & 0 & $\begin{array}{l}\text { Masonary const- } \\
\text { ruction duration } \\
\text { Rec. for crew } \\
\text { composition } \\
\text { Max. productivity } \\
\text { estimate }\end{array}$ & $\begin{array}{l}\text { Heirarchial, Rule-based; } \\
\text { OPS5; CMU, PA }\end{array}$ \\
\hline CRANES & 0 & Site plan & $\begin{array}{l}0 \\
0\end{array}$ & $\begin{array}{l}\text { Possible crane } \\
\text { locations } \\
\text { Crane size } \\
\text { Cost of alternative } \\
\text { solutions }\end{array}$ & $\begin{array}{l}\text { AMDAHL, PDP-11, PROLOG } \\
\text { University of Reading, } \\
\text { UK }\end{array}$ \\
\hline $\begin{array}{l}\text { PROPICK- } \\
\text { Selection } \\
\text { of a contract } \\
\text { Type }\end{array}$ & 0 & $\begin{array}{l}\text { Project } \\
\text { objectives }\end{array}$ & 0 & $\begin{array}{l}\text { Conflicts in } \\
\text { project } \\
\text { objectives } \\
\text { Appropriate } \\
\text { form of contract }\end{array}$ & $\begin{array}{l}\text { PC, Deciding Factor; } \\
\text { CM consultants, } \mathrm{CA}\end{array}$ \\
\hline DSCAS & 0 & $\begin{array}{l}\text { Differing } \\
\text { site conditions }\end{array}$ & 0 & $\begin{array}{l}\text { Entitlement } \\
\text { with } \\
\text { justification } \\
\text { No entitlement }\end{array}$ & $\begin{array}{l}\text { Rule-based; IBM PC, TI, } \\
\text { PERSONAL CONSULTANT } \\
\text { PLUS, ROSIE; University } \\
\text { Colorado, CO }\end{array}$ \\
\hline PLATFORM & 0 & $\begin{array}{l}\text { Activity name, } \\
\text { duration, } \\
\text { successors, and } \\
\text { political risks }\end{array}$ & 0 & $\begin{array}{l}\text { Automated } \\
\text { schedule } \\
\text { updating }\end{array}$ & $\begin{array}{l}\text { Frames; XEROX, KEE; } \\
\text { Stanford University and } \\
\text { IntelliCorp, CA }\end{array}$ \\
\hline $\begin{array}{l}\text { PLATFORM } \\
\text {-III }\end{array}$ & 0 & Project data & 0 & $\begin{array}{l}\text { Project } \\
\text { feasibility } \\
\text { under } \\
\text { uncertainty }\end{array}$ & $\begin{array}{l}\text { Frames: XEROX, KEE; } \\
\text { Staford University and } \\
\text { IntelliCorp, CA }\end{array}$ \\
\hline $\begin{array}{l}\text { Predicting } \\
\text { Time and } \\
\text { Cost of } \\
\text { Construction } \\
\text { during initial } \\
\text { design }\end{array}$ & 0 & $\begin{array}{l}\text { Activity } \\
\text { details, and } \\
\text { resources }\end{array}$ & 0 & $\begin{array}{l}\text { Time and cost } \\
\text { of activities }\end{array}$ & $\begin{array}{l}\text { IBM PC; PROLOG; } \\
\text { University of Reading, } \\
\text { UK }\end{array}$ \\
\hline
\end{tabular}




\begin{tabular}{|c|c|c|c|c|c|}
\hline $\begin{array}{l}\text { Military } \\
\text { Constr- } \\
\text { uction } \\
\text { Army-Cycle } \\
\text { Analysis }\end{array}$ & 0 & $\begin{array}{l}\text { Data on } \\
\text { army } \\
\text { facilities }\end{array}$ & 0 & $\begin{array}{l}\text { Status of } \\
\text { each project }\end{array}$ & $\begin{array}{l}\text { XEROX, TI; KEE, InterLISP; } \\
\text { US Army, CERL }\end{array}$ \\
\hline $\begin{array}{l}\text { Constr- } \\
\text { uction } \\
\text { Schedule } \\
\text { Analysis }\end{array}$ & 0 & $\begin{array}{l}\text { Project and } \\
\text { activities } \\
\text { data }\end{array}$ & 0 & $\begin{array}{l}\text { Status of } \\
\text { project schedule } \\
\text { Revision of } \\
\text { activity durations }\end{array}$ & $\begin{array}{l}\text { IBM PC, PERSONAL CONSUL } \\
\text { TANT PLUS; US Army, } \\
\text { CERL }\end{array}$ \\
\hline
\end{tabular}

\section{DEVELOPMENTAL EXPERT SYSTEMS}

\begin{tabular}{|c|c|c|c|c|c|}
\hline SITEPLAN & 0 & $\begin{array}{l}\text { Available } \\
\text { space }\end{array}$ & 0 & $\begin{array}{l}\text { Project site } \\
\text { layout } \\
\text { Updating of } \\
\text { site plan }\end{array}$ & $\begin{array}{l}\text { Blackboard Architecture; } \\
\text { XEROX; Stanford Univ. C }\end{array}$ \\
\hline IPMS85/2 & o & $\begin{array}{l}\text { Job time } \\
\text { and cost data }\end{array}$ & 0 & $\begin{array}{l}\text { Evaluation of } \\
\text { project } \\
\text { personnel }\end{array}$ & $\begin{array}{l}\text { Rule-based, IMST; } \\
\text { MIT }\end{array}$ \\
\hline CPO-ES & 0 & $\begin{array}{l}\text { Project } \\
\text { details }\end{array}$ & 0 & $\begin{array}{l}\text { Appropriate } \\
\text { project } \\
\text { organization } \\
\text { Evaluation of existing } \\
\text { project organization }\end{array}$ & $\begin{array}{l}\text { Deciding Factor; } \\
\text { ETH, Zurich, Switzerland } \\
\text { g }\end{array}$ \\
\hline $\begin{array}{l}\text { PROJECT } \\
\text { PLANNER }\end{array}$ & $\begin{array}{l}0 \\
0 \\
0 \\
0\end{array}$ & $\begin{array}{l}\text { Project data } \\
\text { In-house } \\
\text { expertise } \\
\text { Level of } \\
\text { uncertainty } \\
\text { Market } \\
\text { conditions }\end{array}$ & $\begin{array}{l}0 \\
0 \\
0\end{array}$ & $\begin{array}{l}\text { Optimal project } \\
\text { delivery system } \\
\text { Contracting plan } \\
\text { Project organiza- } \\
\text { tion } \\
\text { Total indirect costs }\end{array}$ & $\begin{array}{l}\text { Rule-based; IBM PC/XT; } \\
\text { INSIGHT2+; State Univ. } \\
\text { of New York at Buffalo. }\end{array}$ \\
\hline
\end{tabular}

An expert system 'PROJECT PLANNER' is being developed at the department of civil engineering, State University of New York at Buffalo. This expert system is briefly described in the following sections with a view to illustrate the typical characteristics of expert systems. 
PROJECT PLANNER - An Expert System for the Planning of Construction Projects. This expert system will consist of four modules:

(i) Module 1: PDSS - Project Delivery System Selector

(ii) Module 2: MCPS - Matching Contracting Plan Selector

(iii) Module 3: POSP - Project Organization Structure Planner

(iv) Module 4: TICC - Total Indirect Costs Calculator

The four modules will interact as in Figure 2. The PDSS will select an initial project delivery system and then the MCPS will propose a matching contracting plan. The POSP will use the results of PDSS and MCPS to propose an organization structure and feed into TICC for computing the management and other indirect costs. These costs will be fed back into the PDSS which might reconsider its choice of a project delivery system, in which case the whole cycle will repeat. This process will continue until all of the four solutions generated by the PROJECT PLANNER are within the acceptable ranges.

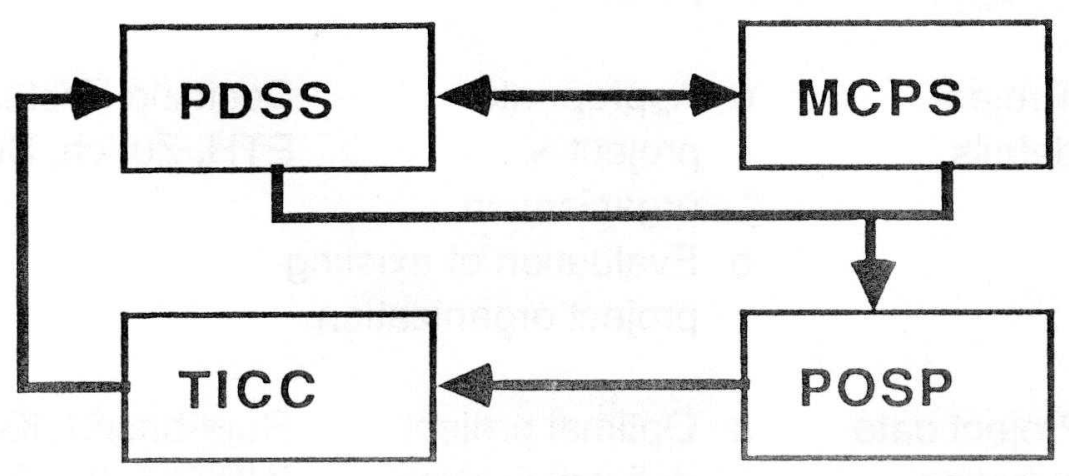

Figure 2: INTERACTION OF THE FOUR MODULES OF THE PROJECT PLANNER

The PROJECT PLANNER expert system is being implemented on an IBM PC/XT computer using INSIGHT2 + expert system shell developed by Level Five Research, Inc. of Florida, U.S.A. The knowledge acquisition phase of the first module: PDSS is in progress. This first module is expected to be completed within the next 6 months. The following project delivery alternatives are 
included (3) in PDSS module:

1. Traditional

2. Fast Track Const. Management

3. Design-Build Process

4. Turn-key Approach

The PDSS is designed to use the following criteria in the selection of a project delivery system:

1. Project Time Constraint

2. Project Size

3. Project Complexity

4. Competetive Bid Requirement

5. Owner Involvement

6. In-house Expertise

7. Level of Uncertainty/Claims

8. Local/Global Market Conditions

Figures 3 illustrates a consultation session with the PDSS expert system module. The various screens shown are based on the design plan and are not taken from an actual consultation session.

Figure 3: A DIALOG WITH PDSS EXPERT SYSTEM MODULE

(The first screen briefs the user about some procedures)

Welcome to PDSS - Your Project Delivery System Selector

- Please answer my following questions.

o lif you donot have an answer, type 'UNKNOWN'.

- Assign your degree of belief, from 0 to 1, to each answer.

o For assistance type "?'.

o For understanding the basis of my advice, press function key 'F4'.

(In the following screens, User's responses are marked with double asterisks and typed in capital). 
(1) What is the Name of your Project?

** MEGA MALL

(2) What is the Size of MEGA MALL?

Large Medium Small

$(>500 \mathrm{~m}) \quad.\left(50-500 \mathrm{~m}_{\mathrm{s}}\right) \quad(<50 \mathrm{~m}$.

** LARGE

(3) What is the Nature of the MEGA MALL ?

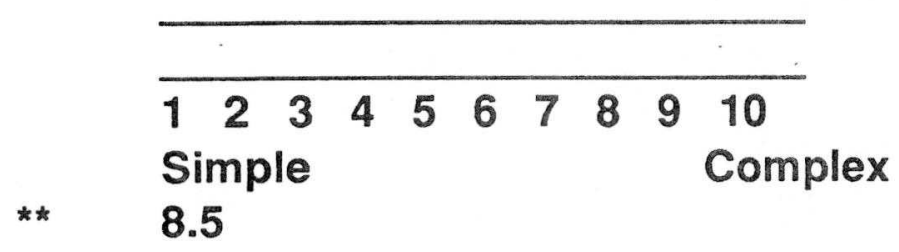

(4) Is this a Public Project?

** NO

(5) Do you want to be involved with day-to-day decisions during the construction of MEGA MALL ?

** NO

(6) How is your Time-constraint? (The user wants to know the

meaning and ranges of time-constraint)

** ?

$?$

(Help Screen)

TIGHT

(7) Are the Performance Requirements clearly defined?

** YES (.8)

THANK YOU!

(PDSS selects a Project Delivery System)

Go for DESIGN-BUILD Project Delivery System. 
** $\quad F 4$

(i) Your time-constraint eliminates traditional system (Rule 13).

(ii) Relatively clear performance requirements (.8) prefer DESIGN-BUILD process over TURN-KEY (Rule 32).

(iii) You do not wish to be involved in day-to-day working, and the job is relatively large and complex; FAST TRACK CM Approach has the potential of design-related claims (Rules $44,76 \& 112$ ).

(Rule-based expert systems store knowledge in IF-THEN rules; a sample rule from the PDSS expert system is shown below)

\section{A SAMPLE RULE FROM PDSS:}

IF:

1) The Project SIZE is LARGE

2) The Project NATURE is COMPLEX, AND

3) The TIME-CONSTRAINT is TIGHT

THEN: 1) Eliminate TRADITIONAL (1.0)

2) Prefer DESIGN-BUILD over TURNKEY (.6)

\section{Potential Expert Systems}

\section{Application Areas in Construction}

Several planning, engineering, management and operational tasks are candidates for expert system formulation and their effective application. A list of potential application areas has been attempted in the following sections $(5,8)$ :

Design of Construction Methods. The various candidate topics include: configuration of crews; choice of construction methods; man-machine trade-offs; choice of transportation mode for the movement of materials, personnel and equipment; selection of optimum sizes, configurations and 
methods of jointing of various components in modular construction; and deep excavations.

Concrete Mixing and Placement. The subsystems that need decisions include: mix design to meet performance standards for a variable set of site conditions and materials; choice of a placement method; configuration of crushing, batching and transportation equipment; and design of formwork.

Constructability Evaluation. Some important issues include: choice of construction materials; selection of the best design-function-cost combination; bid-packaging; and choice between prefabricated and in-situ construction.

Temporary Facilities Layout. Optimal layout of temporary facilities that can have a significant effect on productivity such as access roads, parking areas, change rooms, material lay down areas, fabrication shops, site office and hoisting equipment.

Project Planning, Scheduling and Control. Some candidate tasks in this area include: developing variable time-cost estimates of activities; generation of construction schedules; critical path analysis; resource allocation; time and cost control; diagnosing reasons for time, cost or resource over runs; prescribing remedial actions; and cost estimating.

Project Management. Several kinds of expert systems that could be built in this area include: choice of a project delivery strategy; selection of a contract type; quality assurance and control; construction contract formulation; project financing options; $A / E$ and $C M$ selection; prequalification of contractors; bid evaluation; evaluating progress payments; evaluating claims; management of risks; and evaluating the quality of a constructed component or facility.

Construction Company Management. The various candidate topics that can help a construction company include: bidding strategy; financial planning; and equipment policy decisions.

Equipment Selection, Diagnosis and Repair. The various candidate problems in this area include: selection of equipment types, sizes and combinations; diagnosis and monitoring of equipment condition; and repair and preventive maintainence and procedures based on operational behavior. 
Human Resources Management. The various candidate topics in this area include: designing project and company organization structures; personnel management; labor relations; safety management; and productivity improvement techniques.

Operational Problems in Constructed Facilities. Some important problems that are usually solved using heuristics include: causes and remedial actions for functional failures such as leaking, sweating, poor ventilation and temperature control; causes and remedial actions for structural failures such as foundation settlement and cracking; post hazard damage assesment of facilities; and rehabilitation methods.

Materials Management. Some candidate topics in this area include: choice of materials; scheduling order and movement of materials; materials handling and testing; and storing and use of explosives.

\section{Architecture of An Expert System}

The principal distinction between expert systems and algorithmic computer programs lies in the organization of knowledge. A traditional algorithmic application is organized into data and algorithm, Figure 4(a). Algorithm contains domain knowledge and computer program which uses the data organized in a rigidly defined format to solve a specific problem. Human knowledge consists of small fragments organized in a random manner and therefore does not fit this model. An expert system separates the algorithm into a knowledge base (KB) and a control program, as illustrated in Figure 4(b). The KB contains all the factual knowledge and heuristics about the specific domain and the control program or inference machine manipulates the KB. The data portion or context describes the problem being solved and the current state of the solution process.

A schematic of a rule-based expert system is shown in Figure 5 (8). It is to be emphasized that only the knowledge base is domain specific. All the other components are parts of a general purpose expert system building framework applicable to other application domains. The key components of an expert system are: 
1. Knowledge Base

2. Inference Machine

3. Context

4. Explanation Module

5. Knowledge Aquisition Module

6. User Interface

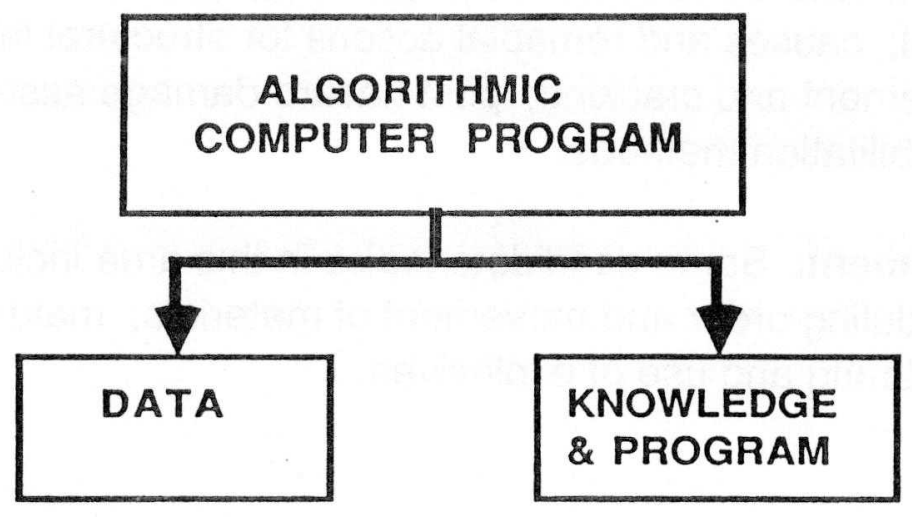

Figure 4(a): ORGANIZATION OF AN ALGORITHMIC COMPUTER PROGRAM

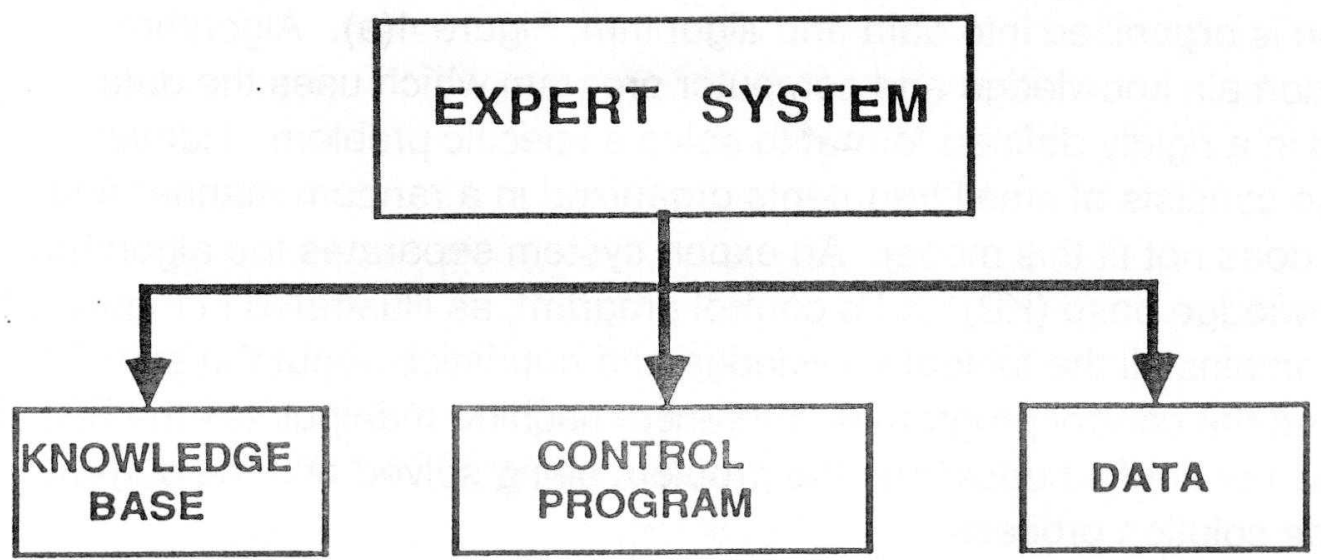

Figure 4(b): ORGANIZATION OF AN EXPERT SYSTEM

1. Knowledge Base: Knowledge base contains a large body of domain specific knowledge gathered from human experts and from other sources like books, periodicals and experiments. An expert system's performance is as good as the size and quality of its knowledge base. This knowledge comprises of: 


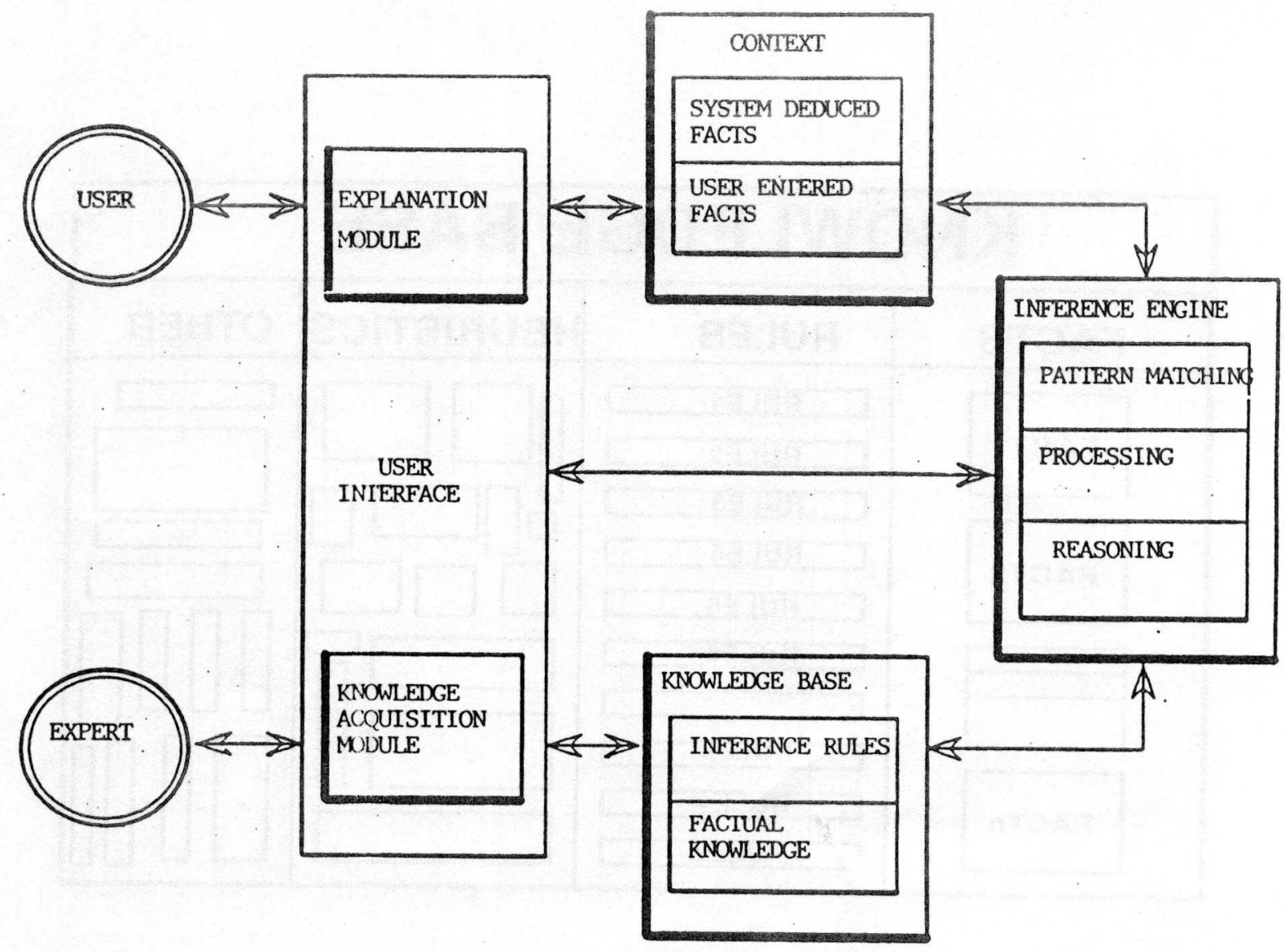

Figure 5: ARCHITECTURE OF A RULE-BASED EXPERT SYSTEM (After (8))
(i) Facts
(iv) Long term historical information
(ii) Rules
(v) Beliefs
(iii) Heuristics
(vi) Assumptions

Unlike algorithmic computer programs, the order of rules in an expert system is not important. The knowledge in the knowledge base is organised into modules, as in Figure 6 , which makes the addition, subtraction and modification of knowledge very easy. 'Facts' correspond to true propositions, and include the set of information that is widely shared, publicly available and generally agreed upon by experts in the field. 'Rules' express plausible propositions; and 'heuristics' are experience based rules of good judgement that characterize expert level decision making in the field. 'Heuristics' prune a search space to a manageable size. 


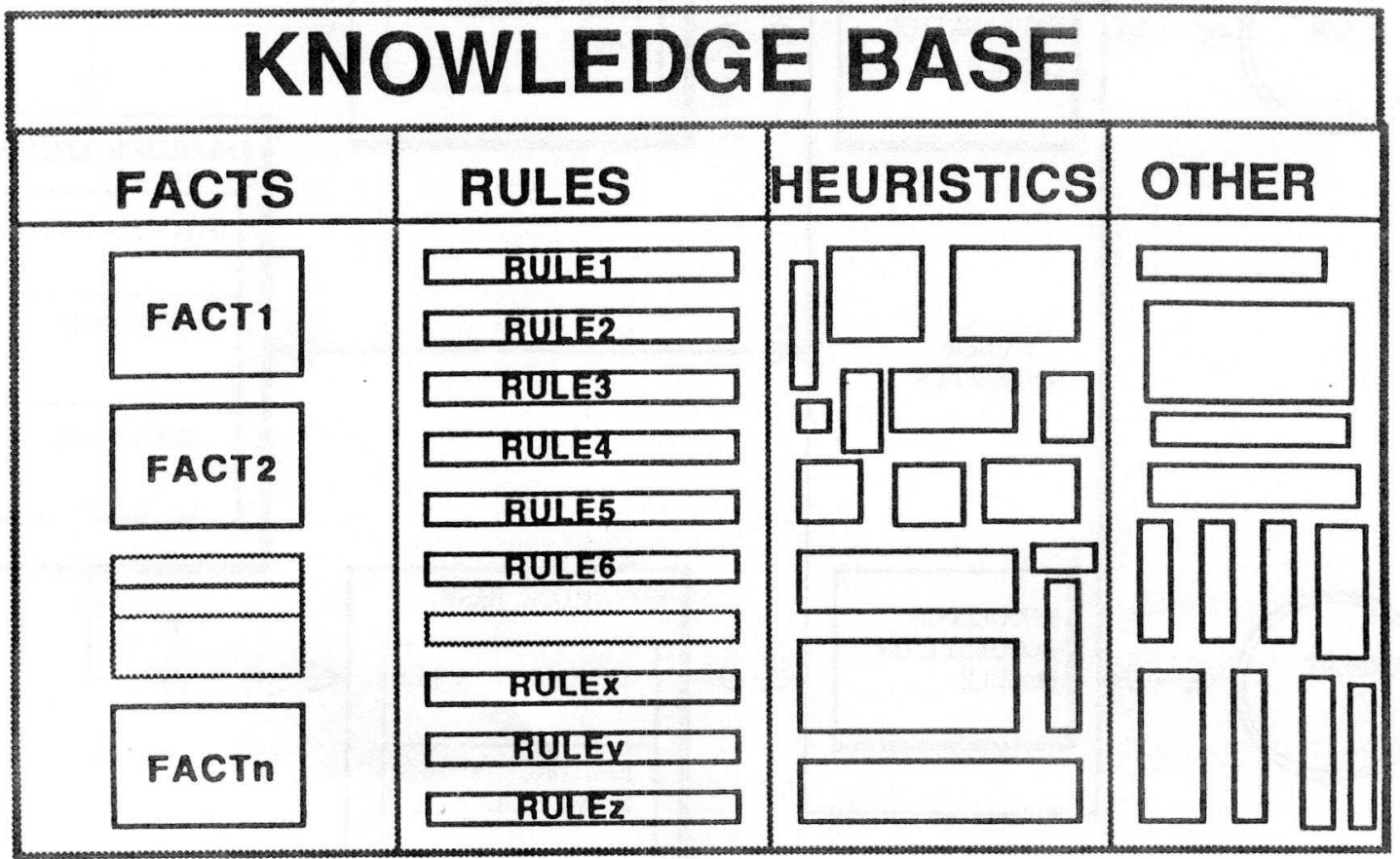

Figure 6: MODULAR STRUCTURE OF A KNOWLEDGE BASE

2. Inference Machine: The inference machine or inference engine operates on the current data base and makes inferences utilizing the knowledge in the knowledge base. A rule-based forward chaining inference machine performs three steps.

(i) Pattern Matching: Matches the current problem data in the context with the premises of rules in the KB and determines which of these currently evaluate to true. This step yields a set of candidate rules.

(ii) Scheduling: Selects one of the applicable rules.

(iii) Knowledge Modification: Fires the corresponding action which updates some items in the context. This process continues until the goal state is reached or until there are no more rules remaining to be fired. 
Expert system inference machines can deal with imprecise or incomplete data. The entering data has associated with it a certainty measure indicating a level of confidence. Rules conditionally fire based on the certainty of the premise. The inference machine computes and gives the inference along with the certainty.

Most inference procedures have been implemented in LISP, a symbolic programming language. Of late, some expert systems are being implemented in ' $\mathrm{C}$ ' and Pascal computer programming languages.

3. Context: The use of an expert system begins with the user introducing his problem by entering some facts about the problem into the context. The context contains the working data of the problem currently being solved. This data may be divided into facts as entered by the user and those inferred by the program.

4. Explanation Module: The user of the expert system has a consultation session on the computer. The expert system asks some questions, and issues a report on the proposed goal. The explanation module makes an expert system transparent in that it provides answers to the following questions at any time during the consultation:

(i) What is the problem solving strategy?

(ii) What is the current line of reasoning ?

(iii) How was a fact deduced?

(iv) How was the goal state reached?

(v) What exists in the static knowledge base ?

5. Knowledge Acquisition Module: Knowledge acquisition (KA) module, also called a KB editor aids in the construction of new knowledge bases. The knowledge from experts and other sources has to be entered in the knowledge acquisition module in a rigid format, in accordance with one of the knowledge representation schemes. Eventually, it will be possible for the experts to enter their knowledge into KA modules and build their own expert systems.

6. User Interface: The interface program makes the output understandable to the user, using a technical subset of English and/or computer graphics, and translates user's input into internal form. 


\section{Conclusions}

Some enthusiasts rank expert systems with steam power, and some with electricity. Some say: with Al technology now in usable form, the second computer revolution has begun. These may be too early assessments. But KBES technology at least parallels the FORTRAN of the 50's, the problem oriented languages of the 60's and the CAD of the 70's. The contribution of expert systems to the extension of human capability and to our effectiveness as managers will be indeed profound. The more we have learnt about expert systems, the more we have become convinced that expert systems will of course change the way people think about solving their problems.

So far, most of us have learnt the hard way, by making mistakes and learning from them, since there was no mechanism to store the domain knowledge and experience of people in a friendly and usable manner. So far, the benefits of computers were more confined to the computer scientists. Al technology has now given us the art of building expert systems which do not require hard core computer scientists. These expert systems, thus, promise to harvest the fruits of computer science and computers to make all of us more productive.

Expert systems have given us a way to collect and organize data which can be used to create information which in turn can be used to help make better decisions, for today as well as for the future. What lies ahead in the use of expert systems in the domain of construction, depends on how useful the construction industry finds these first expert systems. So far, the expert systems research has been confined to the academic and research institutions. The work done in these institutions has shown that expert systems technology has the potential of offering practical tools for making intelligent and fast managerial and technical decisions. The following trends can be safely predicted at this time:

(i) The next few years will see many small operational expert systems, several of them routinely used by the industry. A good number of these expert systems will be capable of interfacing with graphics and database management programs.

(ii) Expert system development requires the domain knowledge to be spelled in a clear, unambiguous and modular format. Therefore, as more and more expert systems are built, the construction knowledge, which is currently dispersed among many individuals, will be consolidated, and 
documented.

(iii) The consolidation of domain knowledge will give rise to the building of larger expert systems which will have frame-based knowledge representation with graphic input and output, will be implemented in more efficient languages like ' $\mathrm{C}$ ', and will run on UNIX operated workstations.

\section{References}

1. Buchnan, Bruce G., and Duda, Richard O., 'Principles of Rule-Based Expert Systems', Advances in Computers, Vol 22, New York, August 1982.

2. Harmon, Paul and King, David, 'Expert Systems: Artificial Intelligence in Business', John Wiley and Sons, Inc., New York, 1985.

3. Helander, Martin, 'Human Factors Ergonomics for Building and Construction', John Wiley \& Sons, New York, 1981.

4. Kim, Simon S. et al,' Survey of the State-of-the-Art Expert/Knowledge Based Systems in Civil Engineering', U.S. Army Corps. of Engineers, CERL, Special Report P-87/01, October 1986.

5. Levitt, Raymond E,'Research Areas for the Application of Knowledge Based Expert Systems to Construction Engineering and Management', white paper for NSF workshop, May 19-21, 1985.

6. Mohan, Satish, 'Expert Systems: How Useful are They in Construction?', Construction Management Symposium, State University of New York at Buffalo, Buffalo, April 1987.

7. Mohan, Satish, 'PDSS-Project Delivery System Selector: An Expert System for Selecting an Optimal Project Delivery System', Paper in preparation.

8. Rehak, Daniel R. and Fenves, Steven J., 'Expert Systems in Civil Engineering, Construction and Construction Robotics', Annual Research Review, Robotics Institute, Carnegie-Mellon University, March 1985.

9. Waterman, Donald A, 'A Guide to Expert Systems', Addison-Wesley Publishing Company, 1986. 